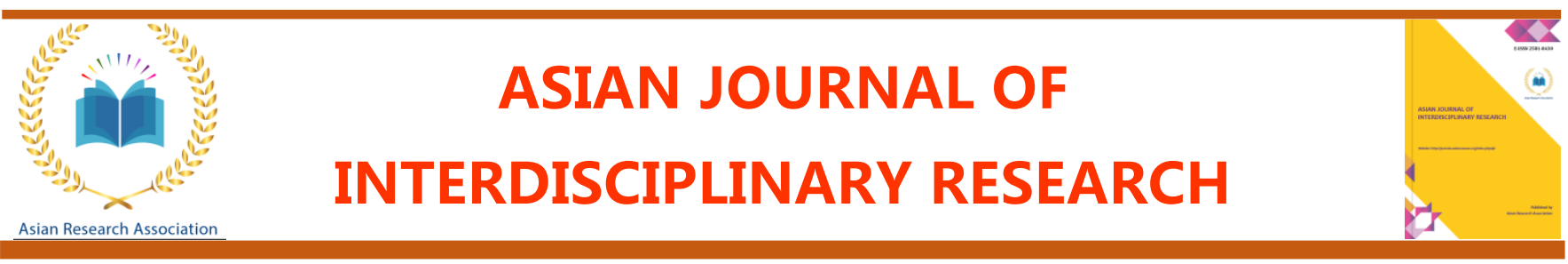

\title{
Analysis of Primary School Students' Attitudes towards the Culture of Life
}

\author{
Edin Kukavica ${ }^{a},{ }^{*}$ \\ ${ }^{a}$ Faculty of Political Science, University of Sarajevo, Sarajevo-71000, Bosnia \& Herzegovina. \\ *Corresponding author Email: edinurjankukavica@gmail.com \\ DOI: https://doi.org/10.54392/ajir2146 \\ Received: 17-07-2021; Revised: 06-11-2021; Accepted: 09-12-2021 Published: 22-12-2021
}

\begin{abstract}
The culture of life is a theological-philosophical term, which signifies a commitment to respect and protect life. The aim of this study was to investigate students' attitudes towards the culture of life in Sarajevo Canton. Research included a sample of 1204 students of $6^{\text {th }}$ grade of primary schools in Sarajevo Canton, divided into two subsamples of 602 students attending schools in suburban and urban parts of Sarajevo Canton, we examined the attitudes of students who acquired competencies in the subject Culture of Living to the aspect of culture as a phenomenon, with all its integral wholes from healthy lifestyles, through general cultural habits to traditional values. The results obtained by factor analysis indicate that students attending schools in the suburbs of Sarajevo Canton determine attitudes that have the premise of education in relation to students attending schools in urban areas of Sarajevo Canton, which are more determined by educational categories of attitudes. to conclude that the children of suburban schools have a greater influence of parents and families on attitudes compared to urban schools where the influence of teachers and schools is greater, based on the attitudes of students through a survey conducted.
\end{abstract}

Keywords: Culture of living, Students, Attitudes, Teaching, New values.

\section{Introduction}

A Culture of Living is living in accordance with basic, fundamental, and crowning moral principles (Benedict, 2019; Keesing, 1974; Williams, 1961). The school education system with an educational structure has caused a gap between what is needed and expected on the one hand and realized on the other (Fullan, 2012), resulting in the complete disappearance or replacement of the internal hierarchy of value criteria, definition criteria and social norms. Causal-consequential new criteria, new values and new norms have been formed that differ significantly from what tradition considers to be classically decent and traditional (Coe, 2017; Sue, 2005).

The problem is more the fact that these are parents, teachers and authorities who have a crucial formative influence on twelve-year-olds on the verge of a crucial formative period - puberty (Družinec, 2016; Puškarić, 2021), which are the target group of this research. It should be borne in mind that in this case, twelve-year-olds "only" represent the medium, ie the source of imprinted knowledge, experiences, opinions, attitudes and prejudices of their authorities from both ends of the scale of total human existence manifested as a culture of healthy living.

This fact, on the one hand, significantly complicates this research and makes it significant, both from a scientific and practical perspective. On the other hand, it in turn brings the general culture of healthy living into the domain of living culture, and raises the Culture of Living as an object to the level of the most important, and unjustly and unjustifiably neglected object, giving it multiple significance because it appears as the only valid and credible channel of return, reaffirming and preserving real tangible and intangible values and aspects of healthy lifestyles, otherwise fully exposed to arbitrariness of interpretation and perception, radicalization and neglect, decay and complete oblivion under the influence of all pseudo-groups claiming its affirmation and abstraction. None of the questions posed before this research, from the theoretical definition of new ethics, new traditions, new culture, new healthy lifestyles, place and role of virtue and ethics of virtue in the process of positive retraditionalization and tasks of the entire educational apparatus is simple and one-sided response. 
The aim of this study was to investigate students' attitudes towards the culture of life in Sarajevo Canton. Therefore, we considered it extremely important to look at and analyze the situation and make a cross-section of the acquired knowledge from the subject Culture of Living, as well as norms of decent, healthy, cultural and civilized behavior of children aged twelve to find guidelines for the beginning and course of positive retraditionalization. necessary if we hope and strive for a healthy and decent society that knows what they are, applies and lives in accordance with the positive values that the tradition of care, ie the culture of healthy living as living a healthy culture.

\section{Materials and Methods}

The cross-sectional study was carried out in Sarajevo - Canton Sarajevo, he biggest city in Bosnia and Herzegovina.

\section{Selection of participants}

Inclusion criteria: 6th grade of primary schools students aged mean $=11.50 \pm 0.5$. A total of 1.204 were divided into two subsamples. Group A - 602 students attend schools located in the inner (urban) city of Sarajevo. Group B - 602 students attend schools located in the suburbs of Sarajevo. Parents of all subjects signed formal consent they have been informed about the purpose and the aim of the research.

\section{Questionnaire}

A specifically designed questionnaire was used to collect data for the research. Online survey based on Lickert's five-point satisfaction scale with 45 questions. A total of 33 questions were selected for this research while 12 questions were rejected because they do not have a satisfactory index and discriminant validity.

\section{Statistical analysis}

Statistical data analyses were performed using SPSS 21.0 for Windows (SPSS Inc., Chicago, USA). The reliability of the measuring particles was performed with the Cronbach's Alpha coefficient. A total of 33 questions were tested with Cronbach Alpha coefficient $(.80)$ and they show the excellent implication of reliability. Also, factor analysis was used to analyze the structure of selected particles.

\section{Results}

Within the table (Table 1. and Table 2) it is possible to see high values of the projections of variables on isolated factors in students. A total of 11 factors were isolated from students attending school in the inner (urban) city of Sarajevo, while a total of 12 factors were isolated from students attending school in the suburban part of Sarajevo.

Table 1 Matrix of the structure of isolated factors of Group A

\begin{tabular}{|l|l|}
\hline First Isolated Factor - Factor of the Culture of Living & \\
\hline I would like the subject Culture of Living to be represented in all grades/classes & .779 \\
\hline I love my homeland and I couldn't live anywhere else & .671 \\
\hline Did you love the Culture of Living? & .607 \\
\hline I apply the knowledge I have from the Culture of Living every day in life & .441 \\
\hline Second Isolated Factor - Factor of Social Awareness and Personal Hygiene & \\
\hline I love when people around me succeed and I like to be in the company of successful people & .750 \\
\hline The idea is... & .647 \\
\hline
\end{tabular}


I am aware that there are children of poorer and better financial status than mine

I wash my hands every time I enter the house

Third Isolated Factor - Ethical Affiliation Factor

I like to hang out with children of other nations

.852

I can hang out with Roma and members of other nations

.804

I am proud to be a member of my own nation, but I respect members of other nations

.665

Fourth Isolated Factor - Factor of Anthropological Awareness

Regardless of whether I know my neighbors, I always greet them first

My family and I respect the basic rules during meals

Vegetables are healthier than hamburgers

Do you visit theaters and museums

Fifth Isolated Factor - Factor of Spiritual Maturity

Would you like to attend religious education classes?

Sixth Isolated Factor - Factor of Traditional Awareness

Authority is...

Truth is...

Cultural heritage are...

Seventh Isolated Factor - Tolerance Factor

Some of my friends have traits that I don't like, but I respect them and they are dear to me

Culture of dialogue is...

Folk clothes are an integral part of our cultural heritage

Eighth Isolated Factor - Factor of Culture of Healthy Living Principles

I feel I belong to the environment in which I live, because it nurtures different cultures and customs

Do you attend classes in Society, Culture, Religion

I like to help students with homework

Joint meal with all family members I have...

I quickly establish connections and acquaintances with peers I did not know before

I try to thank everyone who prepared and served food at home

Ninth Isolated Factor - Etiquette Factor

When I wait for a story to end and then I say what I think

Cultural heritage was created...

Tenth Isolated Factor - Aesthetics Factor

The beauty of the prepared dish is important because...

Eleventh Isolated Factor - Factor of Traditional Culture 
Does your family keep an old object of paintings or a piece of antique furniture, Bosnian rugs or clothes that are carefully preserved since ancient times?

Table 2 Matrix of the structure of isolated factors of Group B

\begin{tabular}{|c|c|}
\hline First Isolated Factor - Factor of Home Education & \\
\hline Do you attend classes of Society, Culture, Religion? & .735 \\
\hline $\begin{array}{l}\text { I feel I belong to the environment in which I live, because it nurtures different cultures and } \\
\text { customs }\end{array}$ & .700 \\
\hline The culture of dialogue is... & .633 \\
\hline National clothes are an integral part of our cultural heritage & .537 \\
\hline Second Isolated Factor - Factor of Living Culture & \\
\hline We visit members of our extended family... & .766 \\
\hline I have a meal with all family members... & .528 \\
\hline Did you love the culture of living? & .488 \\
\hline Third Isolated Factor - Decency Factor & \\
\hline I try to thank the person who prepared and served food at home every time & .743 \\
\hline I like to help students with homework & .652 \\
\hline Fourth Isolated Factor - Ethnicity Factor & \\
\hline I like to hang out with children of other nations & .807 \\
\hline I can hang out with Roma and members of other nations & .722 \\
\hline Quickly establish connections and acquaintances with peers I did not know before & .504 \\
\hline Fifth Isolated Factor - Factor of Traditional Awareness & \\
\hline Truth is... & .853 \\
\hline Cultural heritage was created... & .520 \\
\hline Sixth Isolated Factor - Factor of Traditional Culture & \\
\hline $\begin{array}{l}\text { Does your family keep an old painting or a piece of antique furniture, Bosnian rugs or clothes } \\
\text { that have been carefully preserved since ancient times }\end{array}$ & .817 \\
\hline Regardless of whether I know my neighbors greetings & .472 \\
\hline Seventh Isolated Factor - Factor of Spiritual Maturity & \\
\hline Vegetables are healthier than hamburgers & -.750 \\
\hline Would you like to attend religious education classes? & -.682 \\
\hline Authority is... & -.627 \\
\hline Eighth Isolated Factor - Factor of Tolerance & \\
\hline Some of my friends have traits that I don't like, but I respect them and they are dear to me & .751 \\
\hline I love when people around me succeed and I like to be in the company of successful people & .718 \\
\hline I am proud to be a member of my people, but I respect and members of other nations & .657 \\
\hline
\end{tabular}




\begin{tabular}{|l|c|}
\hline Ninth Isolated Factor - Factor of Cultural Awareness & -.711 \\
\hline I apply the knowledge I have from the Culture of Living every day in my life & -.695 \\
\hline Do you visit theaters and museums? & -.593 \\
\hline When someone's story I wait for it to end and then I say what I think & -.486 \\
\hline The subject Culture of Living will be represented in all grades/classes & -.696 \\
\hline Tenth Isolated Factor - Factor of Social Consciousness & -.646 \\
\hline Idea is... & -.532 \\
\hline I wash my hands every time I enter the house & .790 \\
\hline I am aware that there are children of poorer and better material condition than mine \\
\hline Eleventh Isolated Factor - Cultural Heritage Factor & .717 \\
\hline During meals my family and I respect the basic rules & -.550 \\
\hline Cultural heritage are... & \\
\hline Twelfth Isolated Factor - Mixed Aesthetic-Patriotic Factor & \\
\hline The beauty of the prepared dish is important because... & \\
\hline I love my homeland and I could not live elsewhere & \\
\hline
\end{tabular}

\section{Discussion}

The aim of this study was to investigate students attitudes towards the culture of life in Sarajevo Canton. This study presents one of the first studies of this type in Bosnaia and Herzegovina. Based upon the results of the conducted analyses it is possible to see the isolation of a number of factors both for students attending school in urban and for students in rural areas.

The attitudes expressed by students of Group $A$ (schools in the urban part) determine the influence of the educational part, teacher, school, while in children of Group B the attitudes determine the role of parents or family, where the educational segment is visible. The reason for this is reflected in the fact that parents are increasingly losing their formative role, and their place is beginning to be taken by the peer group (Woodhead, 2006). The process of forming identification matrices and patterns, forming identity based on opinions, attitudes and prejudices, affirmation and negation of decisions and attitudes coincides with the process of self-knowledge, but also knowledge of the environment and is extremely - fundamental and crucial - important for this research. Several studies examining changes in identity status over time have shown an increase in the number of adolescents with more mature identity status and a declining number of adolescents with less mature and less adaptive status. This data indicates the existence of space for parental help and support of teachers during this turbulent formative period (Locke \& Bailey, 2014; Meyers, 2004).

In order to better understand these facts, it is necessary to know and understand the terms "urban" and "rural". Čamo, 2014 states the fact that it is still referred to and reflected in the domain of material - especially in light of superficial interpretation and understanding of the environment - which ultimately determines our frame of reference both in the field of understanding the environment and in terms of understanding oneself (self-knowledge), self-understanding, knowledge of one's place and role in one's environment and in the world and consequently, all other elements of self-identification.

Pedagogical theory and practice are largely limited to the study of a child's intellectual development and tend to emphasize the effect of production, neglecting the importance of his aesthetic development and general cultural development (Kohlberg \& Mayer, 1972; Levinson \& Holland, 1996; Pintrich, 2003). Neglecting the importance of aesthetic development in pedagogical theory and practice has made us aware, moreover, convinced us of the need for a systematic approach to planning, implementing and evaluating aesthetic dimension goals (Erez \& Earley, 1993; 
Kelly, 2009; Visscher-Voerman \& Gustafson, 2004), especially in terms of general culture as living culture, which is best achieved through the subject Culture of Living.

\section{Conclusion}

The paper tries to determine the role, contribution and need for positive retraditionalization of society in terms of self-knowledge and knowledge of the basic characteristics of the environment, reflected in the acquired knowledge, formed opinions and attitudes, possible prejudices and stereotypes about themselves and others among sixth grade students in Sarajevo Canton through the subject of Culture of Living. The results showed us that the Culture of Living as a subject is indispensable and necessary, and in some future reforms of the education system, this unjustly neglected and extremely important subject must be kept in mind. It is extremely important, it is almost impossible to overestimate the importance and role of art and culture of living in education and the effort to give this domain of education the necessary, equal and independent status in relation to other subject areas.

\section{References}

Benedict, R., (2019), Patterns of culture, Taylor \& Francis Group, Routledge, London. https://doi.org/10.4324/9780429054419

Čamo, M., (2014), Edukacijske silnice ruralnog načina života u savremenom (urbanom) društvu, Obrazovanje odraslih, 69-77. https://doi.org/10.53617/issn2744-2047.2014.14.2.69

Coe, R., (2017), Inference and interpretation in research, Research methods and methodologies in education, 3443.

Družinec, V., (2016), Transfer vrijednosti s roditelja na djecu, Školski vjesnik: časopis za pedagogijsku teoriju i praksu, 65(3), 475-488.

Erez, M., \& Earley, P. C., (1993), Culture, self-identity, and work, Oxford University Press, United Kingdom. https://doi.org/10.1093/acprof:0so/9780195075809.001.0001

Fullan, M., (2012), Change forces, Probing the depths of educational reform, Routledge, London. https://doi.org/10.4324/9780203059005

Keesing, R.M., (1974), Theories of culture, Annual review of anthropology, 3(1), 73-97. https://doi.org/10.1146/annurev.an.03.100174.000445

Kelly, A.V., (2009), The curriculum, Theory and practice, Sage Publications.

Kohlberg, L., \& Mayer, R., (1972), Development as the aim of education, Harvard educational review, 42(4), 449496. https://doi.org/10.17763/haer.42.4.kj6q8743r3j00j60

Levinson, B.A., \& Holland, D., (1996), The cultural production of the educated person: An introduction, The cultural production of the educated person: Critical ethnographies of schooling and local practice, 1-54.

Locke, D.C., \& Bailey, D.F., (2014), Increasing multicultural understanding, Sage Publications. https://doi.org/10.4135/9781483319582

Meyers, D.T., (2004), Being yourself: Essays on identity, action, and social life, Rowman \& Littlefield Publishers, United States.

Pintrich, P.R., (2003), A motivational science perspective on the role of student motivation in learning and teaching contexts, Journal of educational Psychology, 95(4), 667. https://doi.org/10.1037/0022-0663.95.4.667

Puškarić, M., (2021), Društvo-obitelj-kultura, University of Pula, Faculty of Educational Sciences.

Sue, D.W., (2005), Multicultural social work practice, John Wiley \& Sons, New York, United States.

Visscher-Voerman, I., \& Gustafson, K.L., (2004), Paradigms in the theory and practice of education and training design, Educational technology research and development, 52(2), 69-89. https://doi.org/10.1007/BF02504840 
Williams, R., (1961), 2. The Analysis of Culture, The long revolution, Columbia University Press, New York, United States, 41-71. https://doi.org/10.7312/will93760-004

Woodhead, M., (2006), Changing perspectives on early childhood: theory, research and policy, International Journal of Equity and Innovation in Early Childhood, 4(2), 1-43.

Funding: No funding was received for conducting this study.

Conflict of Interest: The Author has no conflicts of interest to declare that they are relevant to the content of this article.

\section{About The License}

(C) The Author 2021. The text of this article is open access and licensed under a Creative Commons Attribution 4.0 International License

\section{Cite this Article}

Edin Kukavica, Analysis of Primary School Students' Attitudes towards the Culture of Life, Asian Journal of Interdisciplinary Research, 4(4) (2021) 47-53. https://doi.org/10.54392/ajir2146 